\title{
Technical Efficiency of Corn Farming in Sumbawa Regency
}

\author{
Siti Nurwahidah \\ Faculty of Agriculture \\ Samawa University, \\ Sumbawa Besar, Indonesia
}

\author{
Dwidjono H.D. \\ Faculty of Agriculture \\ Gadjah Mada University \\ Yogyakarta, Indonesia
}

\author{
Lestari Rahayu W. \\ Faculty of Agriculture \\ Gadjah Mada University \\ Yogyakarta, Indonesia
}

\begin{abstract}
This research was done on 100 farmers on corn farming location in dry land and 100 farmers on corn in wet land in Sumbawa regency. It used Cobb-Douglas, $t$ test and Stochastic Frontier version 4.1. The results indicate that productivity of corn farming in dry wet land is greater than that in dry land. Results of data estimation using FRONTIER 4.1c indicate that average technical efficiency on dry land and wet land are 0.86 and 0.85 . Scores of frontier production gamma in dry land and wet land are 0.697 and 0.522 . It indicates that $70 \%$ technicalefficiency in dry land is due to managerial capability of farmer and the remaining is influenced by natural factor or weather. Meanwhile in wet area, $55 \%$ is caused by farmer capability in management and the remaining is natural factor.
\end{abstract}

\section{General Terms}

Production Efficiency

\section{Keywords}

Corn farming, efficiency, productivity, dry land, wet land, Frontier $4.1 \mathrm{c}$

\section{INTRODUCTION}

Corn agribusiness development is a movement of ruralbased economic development acceleration through optimization of natural resource, artificial resource and farmer resource management to increase farmer income and welfare. Increase in agricultural production in Sumbawa regency till end of 2011 was still prioritized in improvement of rice production, palawija (soybean, corn, mung bean, cassava) production and horticulture development particularly vegetable and fruit crops [1]

Rural agribusiness institution that grows from bottom and benefits much people is a requirement for sustainable adoption of innovation technology. Past experience teach us that technology adoption did not continue after the project end. One of cause is no rural institution that can supply farmer needs such as seed, fertilizer, working capital and marketing facility [2].

Sumbawa regency as one of regencies in West Nusa Tenggara have great potential to develop corn, because it has climate, soil type and topography that support good corn development both in dryland and wetland. Considering biological potential and increase in corn demand, it is necessary policy that supports the commodity development to be superior commodity to accelerate economic life in Sumbawa regency.

Dryland is one of agroecosystem having great potential for agriculture, for food crop, horticulture and perennial plant as well as livestock. Considering wide land availability and great variations of farming, dryland is potential and can play big role in providing agricultural business than wetland in the future. Agricultural census in 1983 and 1993 indicated that there was increase in household using dryland, when use of wetland decreased due to functional shift [3]. It indicated that role of dryland farming as income source and employment is increasingly higher. Therefore, making dryland function as productive area based on agribusiness need consideration.

In irrigated land in West Nusa Tenggara, there is tendency that corn planting have shifted soybean as second plant after rice. In addition, in dryland it has been done corn planting orienting on market by planting Lamuru variety that is relatively resistant to dryness compared with other varieties. With non soil processing technology farmers can reduce cost they expend. Business persons have also read market opportunity for corn. It is indicated with emerging corn business person in this country. However, based on fact, corn agribusiness have not run yet optimally [4].

In essence farming is as corporation. So, before manage their farming farmers or producers will consider cost and income by allocating available resource in effective and efficient manner to obtain high profit in certain time. It is said effective when farmer or producer can allocated their resource well and efficiently when they use their resource by producing output exceeding input. Unachieved efficiency in farming are due to less farmer knowledge in using limited production factor, difficulty in obtaining production factor in appropriate amount and outside factors such as climate, geographical condition, temperate and so on [5].

This research was intended to identify efficiency level of corn farming in dryland and wetland in Sumbawa Regency.

\section{LITERATUR REVIEW}

\subsection{The Previous Studies}

Researches on corn farming efficiency have been done in Indonesia. One of them was Dewi (2012) that studied technical efficiency analysis of production factor usage on corn farming in Bangkalan, Madura. The result indicated that addition of land area, seed and manure will give great influence on corn production than other production factors. Meanwhile, land area, fertilizer, seed, manure and pesticide have positive relation, while use of urea fertilizer, manpower have negative association to corn production. Efficiencymeasurement using Data envelopment analysis (DEA) indicated that corn farming in research site have not reach full technical efficiency because average technical efficiency was $96.9 \%$ with range $75 \%-100 \%$. Technical inefficiency is $3.1 \%$. It indicates that there is chance for corn 
farmer to increase their production by optimizing production factors they have such as technology implementation, using tractor machine and land cultivation [6].

Other research was done by Berliana (2010) on analysis of production efficiency and income on corn farming in Wirosari district of Grobogan regency. It analysis include efficiency level and income from corn farming. Analytical method used Cobb Douglas Regression analysis and Stochastic Frontier. The results indicate that corn farming had the technical efficiency of 0.84 , the price efficiency of 2.14 , and economic efficiency of 1.79 . The value of technical efficiency was close to 1 , meaning that the corn farming was inefficient. The corn farming in Wirosari Subdistrict has still been profitable as indicated by the R/C ratio value of 2.80. To increase efficiency, farmers should be able to use inputs proportionally [7].

Sunanto and Yusmasari (2007) studied financial analysis of corn farming in wet land after rice in Bantaeng Regency of South Sulawesi province. It includes production and income of corn farming. Analytical method used R/C ratio. The results of observation on the growth and production of corn were not significantly different. The corn farming in the wet rice fields shows the the range of production between 5,284 and $5,960 \mathrm{~kg} / \mathrm{ha}$ with income of IDR7,133,535 IDR8,046,513 per ha, so that the income gained reached IDR5,584,660 to IDR $5,733,413$ per ha with R/C of 2.80 3.48 [8].

Meanwhile Kurniawan et al (2007) did research on economic efficiency and competitiveness of corn on dry area in Tanah Laut Regency in South Kalimantan province. It studied aspectsof technical efficiency and allocationefficiencyanalytic, competitive advantage and comparative advantage of corn in dry land and factors affecting its production.Analytical method used stochastic frontier productionfunction, technicalefficiency analysis, allocative and economic efficiency and PAM (Policy Analysis matrix). From the results, it can be concluded that corn production was positively affected by the use of land size, seeds, organic fertilizer, P fertilizer, pesticide, workers and soil dummy, while $\mathrm{N}$ and $\mathrm{K}$ fertilizers had no significant effect. The increased production with extensification could still be carried out by making use of the dry land that has not been cultivated before. Generally, the corn farmers in the site of the study have technically been efficient, but not allocatively and economically efficient. This was because the use of input was excessive, so it was less efficient. The use of $\mathrm{N}$ fertilizer in accordance with recommendation caused the increase of allocative and economic efficiency. The factors such as age, education, experience and membership in farming groups had no significant effect on the farmers' level of technical efficiency. Corn commodity in Tanah Laut Regency had competitive and comparative advantages and are considered being able to finance the domestic inputs. The increase of allocative efficiency by reducing the use of $\mathrm{N}$ fertilizer in accordance with recommendation caused the increase of competitiveness [9].

Warsana (2007) did analysis of efficiency and profit of corn farming with case study in Randublatung district of Blora regency. Analysisaspect includes profit level, farming efficiency level and corn farming scale level. Analytical method used Cobb-Douglasprofit function, Zeller's Method of Seemingly Unrelated Regression, farmingscale and relative economic efficiency. The results indicate that seeds and pesticide was not optimal, while the allocation of variable input such as workers and pesticide has reached an optimal rate. The estimation of farming scale indicates that the condition of farming scale was averagely in the increasing returns to scale. The results of relative economic analysis between the two groups based on the scale of land size, i.e. the scale of land size under 1.0 ha (small farmers) and that above $1.0 \mathrm{ha}$, show that there was difference in efficiency level where the small farmers were more efficient than the bigger farmers [10].

Ketut et al. (2005) did comparative analysis of corn farming with damirrigation in rainy season and dry season in Gerokgak district of Buleleng regency. The research analyzed financial profit of corn farming in rainy season and dry season. It used descriptive analysis and profit analysis. The results indicate that the productivity of workers was significantly different with the average profits gained by the corn farming per hectare of IDR1,290,871 at wet season and IDR $1,757,069$ at dry season with the calculated t of -5.56 , meaning that the profit gained at wet season was lower and significantly different than that at dry season [11].

\subsection{Farming and Production Function}

Farming science is usually defined as science studying how one allocates available resource in effective and efficient manner to obtain high profit in certain time. It is said effective when farmer or producer can allocate their resource as well as possible and it is said efficient when usage of the resource resulted in output higher exceeding input [12]. Production function analysis can be used to predictquantitative correlation between input and output. Production is change of two or more input (resources) to be one or more output (product). Producing needs input, while in general required input in agricultural sector is capital, man power and technology. Therefore, there is correlation between production and input in which maximal output is resulted from certain input that is called as production function [13]. Production function is a mathematical or quantitative description of various technical production possibilities that is faced by enterprise. Production function gives maximal output in physical meaning from each output level [14]. Production function that is often used as analytical tool in research using econometric approach is Cobb-Douglas production function [15]. Mathematical formula of Cobb-Douglas production function is

$\mathrm{Y}=\mathrm{a} \mathrm{X}_{1}^{\mathrm{b} 1} \mathrm{X}_{2}^{\mathrm{b} 2} \ldots \ldots \mathrm{X}_{\mathrm{n}}^{\mathrm{bn}} \mathrm{e}^{\mathrm{u}}$

where :

$\mathrm{Y}=$ dependent variable

$\mathrm{X}=$ Independent variable

$\mathrm{a}=$ intersep (constant)

$\mathrm{b}=$ parameter for each input $\mathrm{xi}$

$\mathrm{u}=$ disturbance term

$\mathrm{e}=2,718$ (natural logarithm)

\subsection{Stochastic Frontier Production}

One of methods to estimate technical efficiency is frontier stochastic analysis that its implementation used stochastic production frontier (SPF). The method explains that there are two approached that can be used to measure relative efficiency of farming. The first method is stochastic frontier related to random error and inefficiency measurement. The secondmethod is linear programming technique (data envelopment analysis) that does not consider random error, 
so technicalefficiency is bias. In stochastic frontier model, output is assumed being limited by with stochastic production. Frontier function is production function used to measure how actual production functions over its frontier position. Estimation of stochastic frontier production function in Cobb Douglas function is formulated mathematically as follow : [16].

$\operatorname{Ln}(Y i)=X i \beta+(v i-u i), \quad i=1,2,3, \ldots n$

where :

Ln (Yi) = logarithm of farmer output by $i$

$\mathrm{Xi}=$ variable input used by observation $\mathrm{i}$

$\beta=$ parameter that will be estimated

vi $=$ random effect

ui $=$ random variable that describe technical efficiency

Random error (vi) is calculated to measure error and other random factor such asweather, mistake, luckiness, and others in output variable simultaneously with combination effect of a input variable that is not defined in a production function. Aigner et al (1997) assume that vi is normal random independently and identically distributed variable with null means and constant variant. Meanwhile independent variable (ui) is assumed as independent and identically distributed exponential [17]. Stochastic frontier concept with two error terms used in production function is formulated mathematically as follow :

$$
\mathrm{Yi}=\mathrm{f}\left(\mathrm{X}_{\mathrm{i}}, \beta\right) \varepsilon i^{\text {i-ui }}
$$

where :

Yi = output resulted by $\mathrm{i}$ observation

$\mathrm{X}_{\mathrm{i}}=$ variable used by observation $\mathrm{i}$

$\beta=$ parameter coefficient

$\varepsilon \mathrm{i}=$ special error of observation i.

Other name of stochastic frontier model is composed error model because error term consist of two components as follows :

$$
\varepsilon i=v i-u i \quad i=1,2,3, \ldots, n
$$

Component of vi is error because external factor (such as climate) that is assumed follow symmetric normal distribution $\left(\mathrm{vi} \approx \mathrm{N}\left(0, \sigma_{\mathrm{v}}{ }^{2}\right)\right.$, while ui is error because it is internal factor that can be controlled by farmer that describe farmer managerial capability. The component is distributedasymmetrically (ui $>0$ ) or half normal distribution $\left(\mathrm{vi} \approx\left|\mathrm{N}\left(0, \sigma_{\mathrm{v}}^{2}\right)\right|\right.$. If production process is fully efficient, reached production equal to its potential or ui $=0$. In contrary, in reached production is below its potential then ui $>0$.

Frontier stochastic production function model become :

$$
\mathrm{Yi}=\mathrm{f}\left(\mathrm{X}_{1}, \beta\right) \varepsilon^{\mathrm{Vi-Ui}}
$$

Or may be detailed as :

$$
\begin{aligned}
\mathrm{Y} & =\mathrm{f}(\mathrm{X} ; \beta) \cdot \exp (\mathrm{v}) \cdot \exp (-\mathrm{u}) \quad \mathrm{v} \leq 0 \text { dan } \mathrm{u} \geq 0 \\
\mathrm{ET} & =\mathrm{Y} / \mathrm{f}(\mathrm{X} ; \beta) \cdot \exp (\mathrm{v}) \\
& =\mathrm{f}(\mathrm{X} ; \beta) \cdot \exp (\mathrm{v}) \cdot \exp (-\mathrm{u}) / \mathrm{f}(\mathrm{X} ; \beta) \cdot \exp (\mathrm{v}) \\
& =\exp (-\mathrm{u}) \quad 0 \leq \mathrm{TE} \leq 1
\end{aligned}
$$

\section{THE RESEARCH METHODOLOGY}

It used descriptive analytical method as basic method. Research site was determined purposively in Sumbawa regency with two locations of Utan district (wetland) done in MK-1 harvest season in August 2013 and Labangka district (dryland) in end of rainy season in March 2014. Both districts are corn production center and have great potential as area for developing corn crop in Sumbawa regency. Farmer sample was taken using random sampling including 100 farmers in each district, so total sample was 200. Data used was primary data obtained with observation technique (survey) and interview using questionnaire.

The research used t-test analysis, Cobb-Douglas production factor analysis and Stochastic Frontier 4.1c

\section{FINDINGS}

\subsection{Corn Farming Productivity}

Corn farmingproductivity is productivity resulted during one planting season that is planting season on $\mathrm{MH}$ (OctoberApril) for dry season (Labangka district) and wet land (Utan district) corn planting season in MK1-MK2 (April-October). Average corn productivity in dry land (Labangkadistrict) was $12,183 \mathrm{~kg}$ per farming with average area land of 2 hectare, while average corn productivity in wet land (Utan district) was $6,716 \mathrm{~kg}$ per farming with average land of 1 hectare. Different corn farming productivity in dry land and wet land was analyzed with differential mean test ( $t$ test) as presented in below table 1 :

\section{Table 1.Different Mean Test of Corn Farming} Productivity ton Per Hectare

\begin{tabular}{|l|c|c|c|}
\hline Description & Productivity & Statistical t & Estimated t \\
\hline Wet land & 6.716 & 48.375 & 2.374 \\
Dry land & 6.092 & & \\
\hline
\end{tabular}

Source: analysis of primary data (2014)

Notes: $* * *=$ significantly different on $\alpha=1 \%$

Result of $\mathrm{t}$ test on the above table indicated that statistical $\mathrm{t}$ is greater than estimated $t$ or significant at $\alpha=1 \%$. It informs that corn farming productivity in wet land is greater than corn farming productivity in dry land.

Low corn productivity in dry land is caused by less rainfall or uncertain rainy season that is main obstacle in farming in dry land. Corn farming in dry land depends greatly on rain, excessive or less water in plant cannot be controlled that cause its growth disturbed particularly at inflorescence and cob forming. Less rain may cause small cob.

In dry land (Labangka district) land cultivation and fertilization depends also rain. When its condition is too humid can cause high plant disease. In contrary, whencorn farming in wet land(Utan district) in dry season, corn productivity increase, because the plant can obtain full sunray for photosynthesis process and farmer can regulate water with water pump.

\subsection{Technical Efficiency of Corn Farming}

Analysis of corn farming in research site used Stochastic Frontier approach. Production factors (independent variable) that is estimated influencing corn production is land area, use of seed, amount of urea fertilizerusage, amount of NPK fertilizer usage, amount of Za fertilizer usage, amount ofinsecticide usage, amount of herbicide spraying and amount of man power usage. Result of production function 
estimation with stochastic frontier approach in corn farming is presented in table 2 and 3.

Table 2. Stochastic Frontier production function of corn farming in dryland Sumbawa Regency

\begin{tabular}{|l|r|r|l|}
\hline \multirow{2}{*}{ Variable } & \multicolumn{3}{|c|}{ Dryland } \\
\cline { 2 - 4 } & Coeff & $\begin{array}{c}\text { Standard } \\
\text { Error }\end{array}$ & $\mathrm{t}$ - Ratio \\
\hline Constant & 6.727 & 0.246 & $27.382^{* * *}$ \\
\hline Land area & 0.084 & 0.065 & $1.290^{\text {ns }}$ \\
\hline Seed & 0.828 & 0.079 & $10.432^{* * *}$ \\
\hline Urea & 0.031 & 0.018 & $1.691^{* *}$ \\
\hline NPK & 0.000 & 0.005 & $-0.077^{\text {ns }}$ \\
\hline Za & -0.003 & 0.005 & $-0.600^{\text {ns }}$ \\
\hline Herbicide & 0.002 & 0.007 & $0.321^{\text {ns }}$ \\
\hline Insecticide & 0.027 & 0.008 & $3.513^{* * *}$ \\
\hline Labor & -0.001 & 0.014 & $-0.086^{\text {ns }}$ \\
\hline sigma squared & 0.308 & 0.126 & $2.440^{* * *}$ \\
\hline gamma & 0.697 & 0.199 & $3.507^{* * *}$ \\
\hline Mean TE & 0.86 & & \\
\hline
\end{tabular}

Source: analysis of primary data, 2014

Notes:

$* * *)$ significant at level $(\alpha=0.01)(\mathrm{t}=2.374)$

**) significant at level $(\alpha=0.05)(\mathrm{t}=1.665)$

ns: not significant

Based on table $2, \sigma^{2}$ is small. It indicated that distribution or inefficiency error term (ui) is distributed normally. Meanwhile, $\gamma$ is ratio between technical inefficiency(ui) deviation and deviation caused by random variable (vi). $\gamma$ score of farming in dry land was 0.697 and is significant at $\alpha=0.01$. The $\gamma$ score offarming in dry land indicate positive value. It means that technical efficiency of dry land farming is more influenced by farmermanagerialcapability in managing their farming. Based on estimation of stochastic frontier production function model, variable having positive and significant influence on corn production in dry land is seed, urea fertilizer and insecticide usage. Variable of seed amount affect influence significantly (on $\alpha=1 \%$ ) and is positive on production cost. Its coefficient was 0.828 that means additional seed (ceteris paribus) of $1 \%$ will increase production of 0.828 percent. Coefficient of urea fertilizer was 0.031 indicated that addition of urea fertilizer(ceteris paribus) of $1 \%$ will increase production of 0.031 percent. Coefficient of insecticide is 0.027 that means addition of insecticide (ceteris paribus0 of $1 \%$ will increase corn production of 0.027 percent.

Table 3. Stochastic Frontier Production Function of Corn Farming in Wet Land Sumbawa Regency

\begin{tabular}{|l|r|r|l|}
\hline \multirow{2}{*}{ Variabel } & \multicolumn{3}{|c|}{ Wet Land } \\
\cline { 2 - 4 } & \multicolumn{1}{|c|}{ Coeff } & $\begin{array}{c}\text { Standard } \\
\text { Error }\end{array}$ & t- Ratio \\
\hline Constant & 8.067 & 0.298 & $27.102^{* * *}$ \\
\hline Land area & 0.610 & 0.092 & $6.603^{* * *}$ \\
\hline Seed & 0.236 & 0.092 & $2.573^{* * *}$ \\
\hline Urea & -0.004 & 0.017 & $-0.257^{\text {ns }}$ \\
\hline NPK & 0.014 & 0.016 & $0.904^{\text {ns }}$ \\
\hline
\end{tabular}

\begin{tabular}{|l|r|r|l|}
$\mathrm{Za}$ & 0.000 & 0.005 & $-0.079^{\mathrm{ns}}$ \\
\hline Herbicide & -0.003 & 0.009 & $-0.396^{\mathrm{ns}}$ \\
\hline Insecticide & -0.004 & 0.007 & $-0.659^{\mathrm{ns}}$ \\
\hline Labor & 0.012 & 0.024 & $0.512^{\mathrm{ns}}$ \\
\hline sigma squared & 0.325 & 0.142 & $2.295^{* *}$ \\
\hline gamma & 0.552 & 0.355 & $1.552^{*}$ \\
\hline Mean TE & 0.85 & \multicolumn{3}{|l}{} \\
\hline
\end{tabular}

Source: analysis of primary data, 2014

Notes:

***) significant at level $(\alpha=0.01)(\mathrm{t}=2.374)$

**) significant at level $(\alpha=0.05)(\mathrm{t}=1.665)$

*) significant at level $(\alpha=0.10)(t=1.292)$

ns: not significant

In statistical calculation, the $\gamma$ score of farming in wet land is 0.552 and significant at $\alpha=0.1$. The score of 0.552 explain that $55.4 \% 5$ error in technical production function is not caused by random error or stochastic effect such as weather, pest and modelingerror. It means that all variation is outputof frontier production may be considered as effect of technicalefficiency achievement that related to managerial problem in the farming. Based on estimation of stochastic frontier production fungtion, variable influencing positively and significantly on corn production in wet land is land area and amount of seed. Land area and amount of used seed affectsproduction significantly (at $1 \%$ level) and positively. Coefficient of land area was 0.610 that means additional land area (ceteris paribus) of $1 \%$ will increase corn production of 0.6610 percent. Confident of seed was 0.236 indicated that additionof seed (ceteris paribus) of $1 \%$ will increase corn production of 0.236 percent in wet land (Utan district)

\section{CONCLUSIONS}

Result of $\mathrm{t}$ test indicatedthat statistical $\mathrm{t}$ is greater that estimated $t$ or significant at $\alpha=1 \%$. It provides information that corn farming productivity in wet land is greater than that in dry land. Average technical efficiency on dry land and wet land were 0.86 and $0.85 \%$. Gamma score in dry land and wet land are 0.697 and 0.522 . It indicates that $70 \%$ technical efficiency in dry land is due to managerial capability of farmer and the remaining is influenced by natural factor or weather. Meanwhile in wet area, 55\% is farmer capability in management and the remaining is influenced by natural factor. That indicates that developing corn productivity in Sumbawa could be done by improving managerial capability of farmers.

\section{ACKNOWLEDGMENTS}

Our thanks to the Head of the District Department of Food Crops and their Sumbawa field extension staff, who have helped in this research process.

\section{REFERENCES}

[1] Diperta Kabupaten Sumbawa. 2012. Laporan Tahunan Dinas Pertanian Tanaman Pangan Kabupaten Sumbawa

[2] Budiman, H., 2012. Organic Corn Cultivation . New varieties. Pustaka Baru Putra. Yogyakarta

[3] Wedastra, M.S., 2011. Empowerment Potential -Based Agribusiness Dryland Agriculture in West Lombok. GaneC Swara Journal, Vo. 5, No. 2, September 20011. 
[4] Mashur, 2003. Enhance Competitiveness of Agricultural Commodities NTB. BPTP NTB.

[5] Soekartawi. 1990. Economic Theory and Production. Rajawali Press. Jakarta.

[6] Dewi, M.A.R., 2012. Technical Efficiency on Corn Farm Production in Bangkalan, Madura . Thesis. Brawijaya university. Malang.

[7] R. Berliana B.T, 2010 Production Efficiency and Revenue Analysis on Corn Farming in the District Wirosari Grobogan.Thesis. Diponegoro University. Semarang.

[8] Sunanto dan Yusmasari. 2007. Corn effort on Wetland After Rice in Bantaeng South Sulawesi. BPTP South Sulawesi.

[9] Kurniawan, A.Y., Hartoyo, S., dan Syaukat, Y., 2007. Analysis of Economic Efficiency and Competitiveness Maize Dryland in South Kalimantan Tanah Laut . Thesis.IPB. Bogor.

[10] Warsana, (2007). Efficiency Analysis and Benefits of Corn Farming (Case Study In District Randublatung Blora ). Thesis. Diponegoro University. Semarang
[11] Ketut Mahaputra, Nyoman Adijaya and Wayan Trisnawati. 2005. Comparative analysis of the Corn Farming Irrigation Embung On Rainy and Dry Season in Gerokgak Buleleng. BPTP Bali

[12] Soekartawi. 2002. analysis of Farming..Indonesia University Press. Jakarta.

[13] Pindick, R. S., and D. L. Rubinfeld, 2001. Econometric Models and Economic Forescast. McGraw-Hill. New York.

[14] Beattie.B.R. dan C.R, Taylor. 1996. Economic Production. Gajah Mada University Press. Yogyakarta.

[15] Soekartawi. 2003. Economic Theory of Production with Production Function Analysis Coob-Douglas. Raja Grafindo Persada. Jakarta.

[16] Aigner, D.J., C.A.K. Lovell and P. Schmidt, 1977. Formulation and Estimation of Stochastic Frontier Production Function Models. Journal of Econometrics

[17] Coelli, Timothy J., Rao, DS Prasada., O'Donell, Christopher J., Battesse, George E. 1998. an Introduction to Efficiency and Productivity Analysis. Springer. 